\title{
Spheroid-3D and Monolayer-2D Intestinal Electrochemical \\ Biosensor for Toxicity/Viability Testing: Applications in Drug Screening, Food Safety, and Environmental Pollutant Analysis
}

\author{
Evangelia Flampouri \\ Technological University Dublin \\ Shahzad Imar \\ Technological University Dublin, shahzad.imar@tudublin.ie \\ Kieran O'Connell \\ Technological University Dublin, kieran.oconnell@tudublin.ie
}

See next page for additional authors

Follow this and additional works at: https://arrow.tudublin.ie/ittsciart

Part of the Analytical Chemistry Commons, Food Chemistry Commons, Medicinal-Pharmaceutical Chemistry Commons, and the Other Chemistry Commons

\section{Recommended Citation}

Evangelia Flampouri, Shahzad Imar, Kieran OConnell, and Baljit Singh, Spheroid-3D and Monolayer-2D Intestinal Electrochemical Biosensor for Toxicity/Viability Testing: Applications in Drug Screening, Food Safety, and Environmental Pollutant Analysis, ACS Sensors 20194 (3), 660-669, DOI: 10.1021/ acssensors.8b01490

This Article is brought to you for free and open access by the School of Science and Computing at ARROW@TU Dublin. It has been accepted for inclusion in Articles by an authorized administrator of ARROW@TU Dublin. For more information, please contact arrow.admin@tudublin.ie, aisling.coyne@tudublin.ie, gerard.connolly@tudublin.ie. Funder: Enterprise Ireland 
Authors

Evangelia Flampouri, Shahzad Imar, Kieran O'Connell, and Baljit Singh

This article is available at ARROW@TU Dublin: https://arrow.tudublin.ie/ittsciart/100 


\title{
Spheroid-3D and Monolayer-2D Intestinal Electrochemical Biosensor for Toxicity/Viability Testing: Applications in Drug Screening, Food Safety, and Environmental Pollutant Analysis
}

\author{
Evangelia Flampouri, ${ }^{\dagger}$ Shahzad Imar, ${ }^{\dagger}$ Kieran OConnell, ${ }^{\dagger,}$ and Baljit Singh ${ }^{*}, \dagger, \ddagger \odot$ \\ ${ }^{\dagger}$ MiCRA Biodiagnostics Technology Gateway, Technological University Dublin (TU Dublin - Tallaght Campus), Tallaght, Dublin \\ 24, D24 FKT9, Ireland \\ ${ }^{\ddagger}$ Hothouse, Technological University Dublin, (TU Dublin - City Campus), Aungier Street, Dublin 2, D02 HW71, Ireland
}

\section{Supporting Information}

\begin{abstract}
The rise of three-dimensional cell culture systems that provide in vivo-like environments for pharmaco-toxicological models has prompted the need for simple and robust viability assays suitable for complex cell architectural structures. This study addresses that challenge with the development of an in vitro enzyme based electrochemical sensor for viability/cytotoxicity assessment of two-dimensional (2D) monolayer and three-dimensional (3D) spheroid culture formats. The biosensor measures the cell viability/ toxicity via electrochemical monitoring of the enzymatic activity of nonspecific esterases of viable cells, through the hydrolysis of 1-naphthyl acetate to 1-naphthol. The proposed
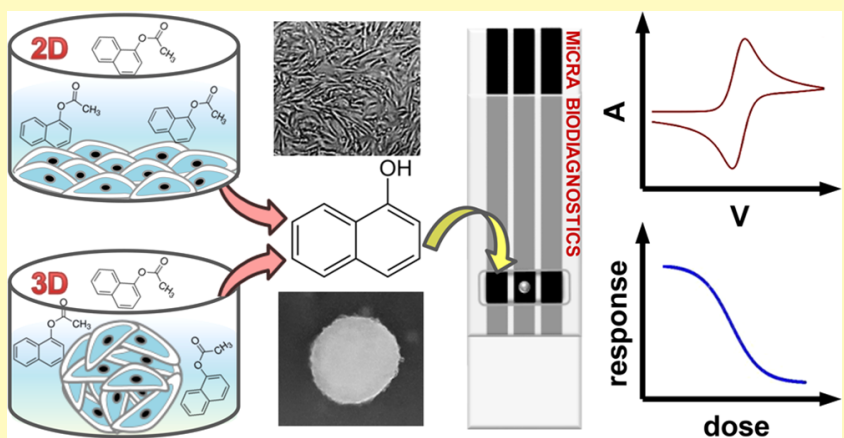
sensor demonstrated strong correlation $(r=0.979)$ with viable cell numbers. Furthermore, the model intestinal toxicants diclofenac (DFC, pharmaceutical), okadaic acid (OA, food-safety), and mancozeb (MZB, environmental) were used for the functional evaluation of the proposed sensor using $2 \mathrm{D}$ and $3 \mathrm{D}$ culture formats. Sensor performance showed high consistency with conventional cell viability/cytotoxicity assays (MTT/CFDA-AM) for all toxicants, with the sensor $\mathrm{IC}_{50}$ values matching the relevant viability $\mathrm{LC}_{50}$ values at the $95 \%$ confidence interval range for $2 \mathrm{D}$ (DCF: $1.19-1.26 \mathrm{mM}, \mathrm{MZB}: 10.28-14.18 \mu \mathrm{M}$, OA: 40.91-77.13 nM) and 3D culture formats (DCF: 1.02-4.78 mM, MZB: 11.26-15.16 $\mu$ M, OA: 162.09-179.67 nM). The presented results demonstrate the feasibility of the proposed sensor as a robust endpoint screening tool for both $2 \mathrm{D}$ and $3 \mathrm{D}$ cytotoxicity assessment.
\end{abstract}

KEYWORDS: spheroid-3D, electrochemical biosensor, screen-printed electrode, cytotoxicity, viability, nonspecific esterase, substrate and enzymatic product

$\mathrm{T}$ he adoption of effective and reliable human-derived in vitro models that will replace animal-based studies is becoming a necessity in the fields of drug screening, food safety, and environmental risk assessment. Conventional toxicological studies rely principally on the use of live animals to analyze the efficacy and toxicity of drug candidates, environmental agents, or food toxicants. ${ }^{1}$ However, the use of animals has been debated as ethically provoking, ${ }^{2}$ costineffective, time-consuming, and low-throughput. ${ }^{3}$ Guiding principles such as the "3Rs", defined as Refinement, Reduction, and Replacement, have contributed to the quest for alternatives to the use of animals, ${ }^{4}$ increasing the need for appropriate in vitro systems for toxicity assessment.

Cell-based platforms that can provide in vivo-relevant biological information have proven to be valuable tools for testing various physiological processes and are widely employed as rapid, inexpensive, high throughput, miniaturized, and automated screening substitutes. ${ }^{5,6}$ Cell based assays are still predominantly dominated by conventional two-dimen- sional (2D) monolayer cultures, where cells are grown in flat layers on rigid materials such as polystyrene or glass surfaces. These long-established cell monolayer cultures, however, do not fully reflect the physiological properties of real tissues and are increasingly recognized as inadequate formats for predicting in vivo behavior. ${ }^{7,8}$

Over the past decades, there is a growing amount of research suggesting that cells grown in three-dimensional (3D) environments simulate more effectively the in vivo cellular behavior of their native tissues, compared to cells grown in classical 2D culture flasks. ${ }^{9}$ Three-dimensional structures demonstrate tissue specific architecture, enhanced cell-cell and cell-extracellular matrix interactions, resulting to tissuelike functionality and in vivo-depictive responses to external stimuli. $^{10,11} 3 \mathrm{D}$ culture models include organotypic explant

Received: November 27, 2018

Accepted: January 30, 2019

Published: January 30, 2019 
cultures such as cell spheroids, microcarrier cultures, and tissue-engineered models. ${ }^{12}$ Multicellular spheroids (MCS) are aggregates of cells, in close contact with each other, which without artificial substrate for cell attachment obtain a symmetric, sphere-shaped form, analogous to tissues. ${ }^{13,14}$ MCS exhibit a characteristic in vivo-like morphology and cellular environment ${ }^{15}$ and have been broadly used in 3D culture methods for tumor models, ${ }^{16}$ hepatic $^{17,18}$ and gastrointestinal $^{19,20}$ culture systems, tissue engineering, ${ }^{21}$ and stem cell biology research. ${ }^{22}$

The measurement of cell viability has an indispensable role in all forms of cell culture and is the principal response measured by cell-based assays for assessing the effect of experimental treatments. ${ }^{23}$ The most commonly used methods to estimate the number of viable eukaryotic cells involve the use of microplate readers, flow cytometers, or high content imaging. The majority of viability methodologies measure some aspect of general metabolism or enzymatic activity, as a marker of viable cells. ${ }^{24}$ Enzyme activity-based viability methods are usually based on the optical, fluoroscence, or luminescence monitoring of substrate consumption or endproduct formation by enzymes such as esterases, oxidoreductases, or proteases. ${ }^{25}$ Among those, esterases are ubiquitous enzymes that hydrolyze aliphatic or aromatic esters, often collectively referred to as "non-specific esterases" (NSE). They are established as viability indicators with numerous commercially available substrates (Calcein, FDA, and CFDA) that, once hydrolyzed by nonspecific esterases, yield fluorescent products. The signal of such probes is proportional to cell viability, as esterase activity decreases in cells with poor vitality. $^{26}$

Despite the continuous research on new probes and stains for improved assessment of cell viability, these assays still have limitations due to their sensitivity to experimental conditions often leading to false-positive or false-negative results. ${ }^{27-29}$

In vitro electrochemical detection methods of cell viability have been emerging as powerful alternatives to most cell based assays, often proclaimed as sensitive, accurate, fast, inexpensive, and easy to use techniques. ${ }^{30,31}$ The global biosensors market is projected to touch US $\$ 25.9$ billion by 2022 from an estimated US\$16.9 billion in 2017, and the electrochemical biosensors are the largest part of the global biosensors market by technology with a 2017 value at US\$12 billion. ${ }^{32}$ In these sensors the biological events are directly converted to an electrical signal, obliterating the need for complex instrumentation and providing advantages in terms of cost, simplicity, and portability. ${ }^{33}$

In the present work, an in vitro electrochemical sensor based on intracellular esterase activity was established for intestinal viability/cytotoxicity assessment, in both $2 \mathrm{D}$ and $3 \mathrm{D}$ cell culture formats. Among the portals of entry for foreign compounds into the human body, the gastrointestinal tract contributes to the first-pass clearance of foodborne or waterborne routes of exposure. ${ }^{34}$ The intestine is an important target of chemical- and toxin-induced toxicity due to its high exposure after oral administration. Considering that the assessment of first-pass metabolism in humans, in particular, the intestinal first-pass, is challenging due to technical and ethical complexities of such studies, ${ }^{35}$ our aim was to develop an electrochemical cell-based approach that could provide cell type specific insight on the biological activity of pharmacological substances, food toxins and environmental pollutants. For this purpose, we investigated whether sensing of the enzymatic hydrolysis of 1-naphthyl acetate by nonspecific esterases of intestinal cells can be used as a viability assay, by electrochemically monitoring the end-product (1-naphthol) as a figure of merit for cellular activity.

Furthermore, the nonsteroidal anti-inflammatory drug (NSAID) diclofenac (DCF), the ethylene bisdithiocarbamate fungicide mancozeb (MZB), and the diarrheic shellfish poisoning toxin okadaic acid (OA), all known for their intestinal toxicity, ${ }^{36-38}$ were used for the functional evaluation of the proposed biosensor and its correlation with established colorimetric and fluorometric cell viability assays. In recent years, it has become progressively clear that, besides the stomach, the small intestine is also a major target organ of NSAID-associated toxicity. ${ }^{39}$ DCF has been reported to induce intestinal injury in both humans and various experimental animal models with typical clinical signs of intestinal toxicity such as small intestinal ulceration, bleeding, and inflammation. ${ }^{36,40} \mathrm{OA}$, another agent with gastrointestinal symptoms, is a polyether fatty acid produced mainly by some species of marine algae, causing diarrheic poisoning in humans after consumption of shellfish that have fed on marine phytoplankton containing the diarrheic toxin. ${ }^{41}$ Based on bioaccumulation studies, in OA poisoning the distribution of the toxin is more pronounced in the intestinal tissue. ${ }^{42}$ Finally, MZB, a fungicide that belongs to the ethylene bisdithiocarbamate group, has also been reported as a gastrointestinal toxicant that exhibits loss of viability in various intestinal epithelium cell lines. ${ }^{38,43}$ All three xenobiotics were selected on the basis of their reported intestinal toxicity and on the fact that they exert their toxic effects via different biochemical pathways. DCF inhibits cyclooxygenases, OA inhibits protein-serine/threonine phosphatases and MZB causes oxidative stress and metal accumulation. $37,49,53$

To the best of our knowledge, this is the first study describing an in vitro electrochemical tool that utilizes the voltammetric monitoring of nonspecific esterase activity in monolayer-2D and spheroid-3D cultures of intestinal cells for viability and toxicity evaluation.

\section{EXPERIMENTAL SECTION}

Materials and Reagents. All materials and reagents were supplied as reported in the Supporting Information (SI).

Cell Culture. HIEC-6 cells (continuous human small intestine epithelial cell line/ATCC CRL-3266), provided by LGC Standards (Teddington, UK), were cultured in OptiMEM Reduced Serum Medium, supplemented with 4\% FBS, $10 \mathrm{mM}$ GlutaMAX, $10 \mathrm{ng} / \mathrm{mL}$ EGF, 100 units $/ \mathrm{mL}$ penicillin, and $100 \mu \mathrm{g} / \mathrm{mL}$ streptomycin, under standard cell culture conditions $\left(5 \% \mathrm{CO}_{2}, 95 \%\right.$ humidity, $\left.37{ }^{\circ} \mathrm{C}\right)$. Cells were maintained routinely in $75 \mathrm{~cm}^{2}$ cell culture flasks, media were replenished every other day, and cells were subcloned through trypsinization (0.25\% trypsin, $0.02 \%$ EDTA) upon $80-90 \%$ confluency. Cell adhesion and monolayer formation were routinely visualized by phase contrast microscopy (Figure $1 \mathrm{~A}$ ), while cell numbers were determined with the use of a Neubauer chamber.

Generation of Spheroids. Multicellular spheroids were generated using the low attachment surface method according to the protocol described by Phung et al. ${ }^{44}$ Briefly, after subcloning, cells were counted and diluted to suspensions of $5 \times 10^{4}$ cells per milliliter of medium. A volume of $200 \mu \mathrm{L}$ of this cell suspension (for 10,000 cells per spheroid per microwell, Figure 1B) was added to each well of U-shaped, 96-well polystyrene plates that had been previously coated with poly-HEMA $(5 \mathrm{mg} / \mathrm{mL})$ to facilitate low attachment. Spheroid formation was initiated by centrifugation of the plates at $1000 \mathrm{~g}$ for 10 $\mathrm{min}$. The plates were then incubated for $48 \mathrm{~h}$ under standard cell culture conditions $\left(5 \% \mathrm{CO}_{2}, 95 \%\right.$ humidity, and $\left.37{ }^{\circ} \mathrm{C}\right)$, which 

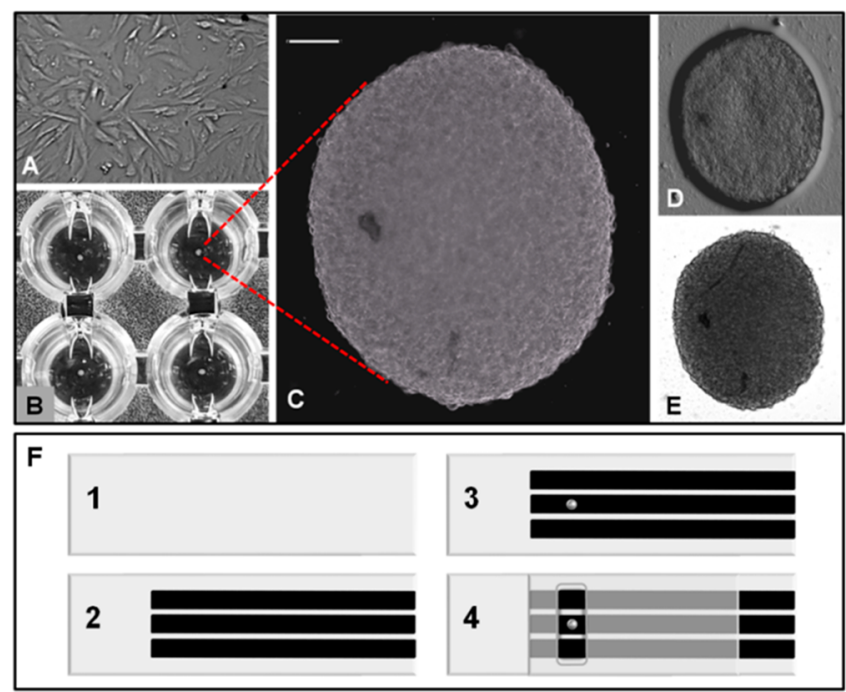

Figure 1. (A) HIEC-6 monolayer culture and (B-E) multicellular spheroids under dark field, phase contrast, and differential interference contrast microscopy; scale bar represents $100 \mu \mathrm{m}$. (F) Fabrication steps of the screen-printed electrode. Carbon ink is printed on a polyester substrate followed by spotting of $\mathrm{Ag} / \mathrm{AgCl}$ ink and finished with an insulating layer.

produced $\sim 400-\mu \mathrm{m}$-diameter spheroids (Figure $1 \mathrm{C}-\mathrm{E}$ ). This size $(\sim 400 \mu \mathrm{m})$ was preferred because spheroids are known to develop a necrotic core around $500 \mu \mathrm{m}$ (diameter), ${ }^{45}$ which could compromise the toxicity studies. Phase-contrast imaging was routinely employed to visualize cell aggregation and spheroid formation.

MTT Assay. Cell viability was assayed with respect to cellular metabolic activity by the MTT reduction assay according to the protocol described by Mosmann ${ }^{46}$ with minor changes as described in the SI.

CFDA-AM Assay. Cell viability was additionally assayed with respect to intracellular esterase activity by the CFDA-AM (5carboxyfluorescein diacetate acetomethyl ester) assay based on the protocol by Ganassin et al. ${ }^{47}$ as described in the SI.

Xenobiotic Exposure. For 2D in vitro exposure, cells (passages 5 to 10) were transferred on clear 96-well plates for MTT viability assays (colorimetric) and onto black 96-well plates for CFDA-AM assays (fluorometric). The cells were allowed to attach themselves for 1 day before xenobiotic exposure ( $24 \mathrm{~h}$, Opti-MEM Reduced Serum Medium, $5 \% \mathrm{CO}_{2}, 95 \%$ humidity, $37^{\circ} \mathrm{C}$ ). For $3 \mathrm{D}$ in vitro exposure, spheroids were transferred onto clear 96-well plates for MTT viability assays and black 96-well plates for CFDA-AM assays. Stock xenobiotics solutions were prepared by dissolving technical grade substances in DMSO. Exposure media were prepared in Opti-MEM Reduced Serum Medium and added to the plates reaching a final
DMSO concentration of $0.05 \%$, which also served as the vehicle control solution.

SPE Fabrication. The SPE stepwise fabrication is shown in Figure 1F. A DEK 248 screen-printing system (semiautomatic screen printer, DEK International, Weymouth, Dorset, UK) was used to fabricate the disposable SPEs. Carbon-ink tracks (3 tracks, $30 \mathrm{~mm} \times 2 \mathrm{~mm}$ ) (Figure 1F) were screen printed on a Melinex 339 polyester sheet (200 $\mu \mathrm{m}$ thickness), obtaining 140 screen-printed electrodes per A4 sheet. The electrode prints were allowed to air-dry at room temperature overnight before the application of an insulation layer (Figure $1 \mathrm{~F}$ ); consisting of a clear polyester layer (Melinex $\mathrm{O}, 100 \mu \mathrm{m}$ ) bonded through $3 \mathrm{M}$ chemical adhesive film $(20 \mathrm{~mm} \times 8 \mathrm{~mm})$ custom designed using CorelDraw graphics suite X5 software (COREL OEM product) and laser machined using a $30 \mathrm{~W} \mathrm{CO}_{2}$ laser cutter (Epilog Zing - Model 10000, USA). The Epilog Model 10000 system is a class $3 \mathrm{R}$ laser product (IEC 60825-1) and complies with 21 CFR 1040.10 and 1040.11 FDA regulations. Subsequently, $\mathrm{Ag} / \mathrm{AgCl}$ paste, which served as the pseudo reference electrode, was spotted $\left(2.8 \mathrm{~mm}^{2}\right)$ onto the middle electrode (Figure $1 \mathrm{~F}$ ) using a glass capillary tube followed by drying at $60{ }^{\circ} \mathrm{C}$ for $2 \mathrm{~h}$. Finally, the electrode prints spotted with $\mathrm{Ag} / \mathrm{AgCl}$ were covered with insulation layer which defined the three-electrode configuration cavity and electrical contacts.

Electrochemical Measurements. Cyclic voltammetry (CV) experiments were performed using the computer-controlled potentiostat $\mathrm{CHI}$ 660C (CH Instruments Inc., Austin, TX, USA). Prior to running each electrochemical experiment, an SPE was connected to the potentiostat through a serial port interface and $20 \mu \mathrm{L}$ of sample or 1-naphthol standards was transferred onto an SPE covering the three electrode cavity (Figure 1F, illustration 4). Sodium phosphate buffer solution (0.1 M, pH 6.5) was employed as supporting electrolyte. CVs were recorded at a scan rate of $100 \mathrm{mV} \mathrm{s}^{-1}$ (vs $\mathrm{Ag} / \mathrm{AgCl}$ ), in the potential range of $-0.20 \mathrm{~V}$ to $+0.55 \mathrm{~V}$, for one cycle. Signal acquisition was realized using $\mathrm{CH}$ Instruments software $(\mathrm{CH}$ Instruments Inc.). All experiments were carried out at ambient temperature of about $25{ }^{\circ} \mathrm{C}$.

Electrochemical Cell Viability Assay Setup. The experimental setup for electrochemical cell viability measurement is shown in Figure 2. Cells at $80-90 \%$ confluence or spheroids of $\sim 400 \mu \mathrm{m}$ diameter were treated with the selected xenobiotics for $24 \mathrm{~h}$. At the end of the exposure period, media were removed and cells/spheroids were gently washed with PBS followed by incubation with $5 \mathrm{mM} \mathrm{1-}$ naphthyl acetate in $0.1 \mathrm{M}$ sodium phosphate buffer ( $\mathrm{pH}$ : 6.5, $0.05 \%$ Triton X-100 for monolayer cultures and $0.1 \%$ Triton X-100 for spheroids) for $2 \mathrm{~h}$. At the end of substrate incubation, $20 \mu \mathrm{L}$ were transferred onto an SPE and CVs were recorded as described above.

Statistical Analysis. Unless stated otherwise, all data were collected from at least three independent experiments. Results are expressed as the mean \pm SD. Differences between means were tested for statistical significance using a one-way analysis of variance (ANOVA), followed by Dunnett's post hoc test. All statistical analyses were carried out with the SPSS Statistics v 20 (IBM Corp., Armonk, NY, USA) except dose response sigmoidal fitting, which was
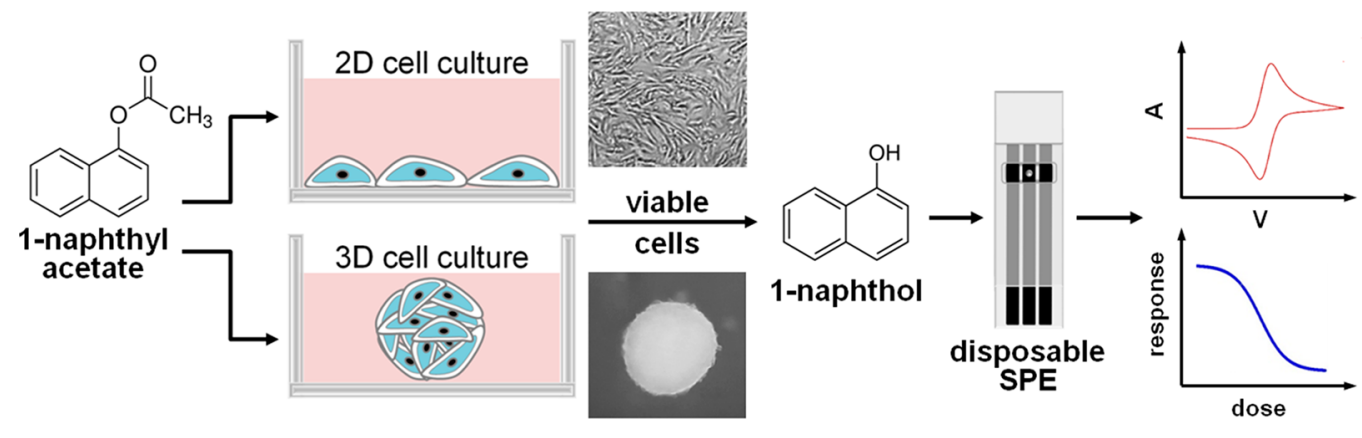

Figure 2. Schematic representation of the $2 \mathrm{D}$ and $3 \mathrm{D}$ sensing principle for cell viability through electrochemical detection of 1-naphthol generated by the nonspecific esterases of viable cells using disposable screen-printed sensors. 
performed with GraphPad Prism 7.04 (GraphPad Software, San Diego, California, USA). The level of probability for statistical significance was established at $p \leq 0.05$ for all analyses.

\section{RESULTS AND DISCUSSION}

Principle of the Proposed Viability Electrochemical Biosensor. Herein, we present a strategy for electrochemically assaying the viability of intestinal $2 \mathrm{D}$ and $3 \mathrm{D}$ cell cultures. Figure 2 illustrates the entire experimental setup of the proposed assay, which utilizes a screen printed electrochemical sensor for measuring the enzymatic hydrolysis of 1-naphthyl acetate to 1-naphthol by nonspecific esterases of viable cells.

Substrate and Product Electrochemistry and Stability Investigations. The electrochemical characterization of 1naphthol $(1-\mathrm{NpOH})$ was carried out by cyclic voltammetry in the potential range between $-0.20 \mathrm{~V}$ and $+0.55 \mathrm{~V}$ at scan rate of $100 \mathrm{mVs}^{-1}$ (vs $\mathrm{Ag} / \mathrm{AgCl}$ ) in sodium phosphate buffer solution (0.1 M, pH 6.5). Figure 3A shows typical CV curves
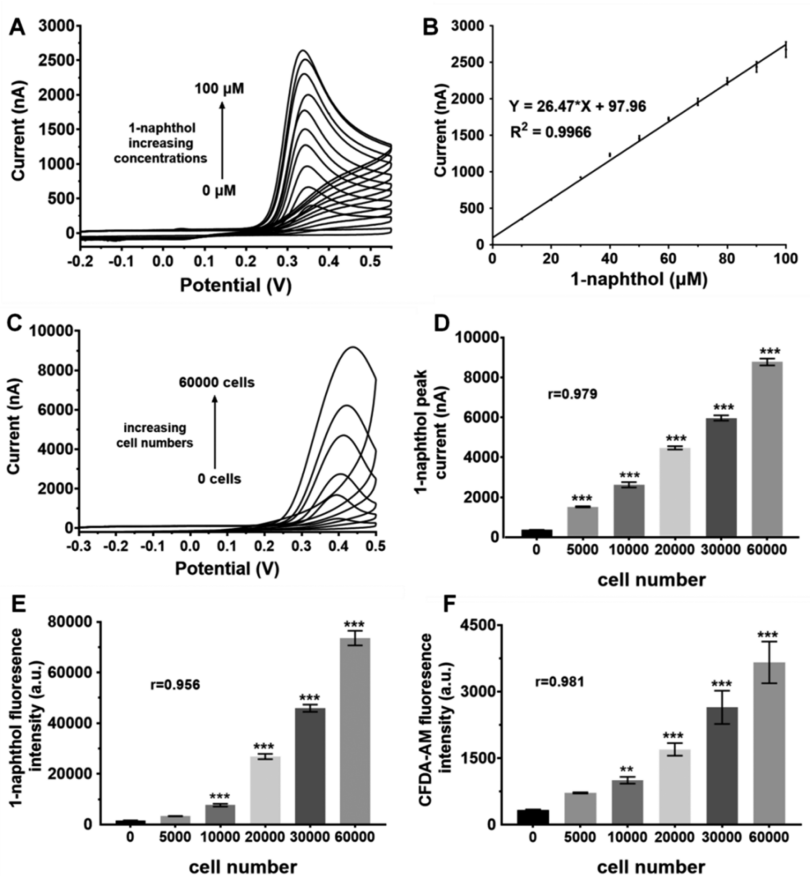

Figure 3. (A) Cyclic voltammograms of a series of 1-naphthol concentrations in sodium phosphate buffer solution (0.1 M, pH 6.5) at a scan rate of $100 \mathrm{mV} \mathrm{s}^{-1}$ ( $\left.\mathrm{vs} \mathrm{Ag} / \mathrm{AgCl}\right)$. (B) Relationship between 1-naphthol concentration $(\mu \mathrm{M})$ and oxidation peak current $(\mathrm{nA})$ values for the data shown in A. (C) Cyclic voltammograms of increasing cell populations and (D) their corresponding oxidation peak values against cell numbers. (E) Fluorescence intensities at 1naphthol's emission max wavelength $\left(\lambda_{\mathrm{em}} \sim 460 \mathrm{~nm}\right)$ plotted against cell numbers. (F) CFDA-AM fluorescence intensity $\left(\lambda_{\mathrm{em}}=530 \mathrm{~nm}\right)$ against cell numbers. Values are expressed as mean \pm SD, one-way ANOVA, Dunnett's test, $* * p \leq 0.01, * * * p \leq 0.001$, vs control.

of solutions containing successively increasing concentrations of $1-\mathrm{NpOH}(0-100 \mu \mathrm{M})$. The carbon SPE showed no obvious electrochemical response in blank solution $(0 \mu \mathrm{M})$, while in the case of $1-\mathrm{NpOH}$, an oxidation process that starts at ca. + $0.25 \mathrm{~V}$ with a single anodic wave reaching a peak potential $\left(E_{\mathrm{p}}\right)$ at around $+0.35 \mathrm{~V}$, was observed. The onset potential for the analyte (1-NpOH) oxidation peak shifts slightly (cathodically, from $+0.25 \mathrm{~V}$ to $+0.22 \mathrm{~V}$ ) with increasing concentration of analyte. This is likely due to the ease of diffusion of the analyte to the interface of the electrode at the higher analyte concentration. During the reverse scan, no cathodic waves or reduction peaks were evident, suggesting that $1-\mathrm{NpOH}$ exhibits an irreversible electrochemical behavior at the carbon SPEs. Overall, the CV curves of the various $1-\mathrm{NpOH}$ solutions reveal that the current response from the oxidation peaks exhibit a strong positive linear correlation with $1-\mathrm{NpOH}$ concentration $\left(R^{2}=0.9966\right)$ in the studied range of $10 \mu \mathrm{M}$ to $100 \mu \mathrm{M}$ (Figure 3B). The limit of detection (LOD) was found to be $2.20 \mu \mathrm{M}$ calculated based on $3 \sigma$ method as described. ${ }^{48}$

The substrate (1-naphthyl acetate, 1-NA) behavior was also interrogated electrochemically before conducting the cytotoxicity and viability experiments. No redox characteristics were observed for the 1-NA at time zero (sodium phosphate buffer solution, $0.1 \mathrm{M}, \mathrm{pH} 6.5$ ) at room temperature ( $\mathrm{RT}, 21{ }^{\circ} \mathrm{C}$ ), but over the time, a peak at around $+0.38 \mathrm{~V}$ start appearing which increases with the time (incubation period). The magnitude of this current is of the order of $\sim 100 \mathrm{nA}(2 \mathrm{~h}, \mathrm{RT}$, $n=3$ ) and found to be a function of time and temperature. This indicates the chemical degradation or autohydrolysis of 1NA over the tested period. Under similar experimental conditions but at $37{ }^{\circ} \mathrm{C}$, a 4.4 -fold signal increase was observed compared to the response at RT, suggesting substrate instability at higher temperatures. To overcome this degradation issue, all following substrate incubations were carried out at RT.

Investigation of 1-Naphthol Production from Viable Intestinal Cells. The generation of 1-naphthol by nonspecific esterases of viable cells was investigated, both electrochemically and fluorometrically, using 1-naphthyl acetate (1-NA) as a substrate. Once 1-NA is in the cytoplasm, nonspecific esterases deacetylate the molecule to convert it to 1-naphthol. For the electrochemical assessment of esterase activity, 1naphthol formation was monitored with cyclic voltammetry using a potential window from $-0.3 \mathrm{~V}$ to $+0.5 \mathrm{~V}$ at a scan rate of $100 \mathrm{mV} \mathrm{s}^{-1}$ (vs $\mathrm{Ag} / \mathrm{AgCl}$ ) in sodium phosphate buffer $(0.1$ $\mathrm{M}, \mathrm{pH}$ 6.5). The CV curves of successively increasing cell populations after incubation with 1-NA (Figure 3C) show that the overall current responses $(1-\mathrm{NpOH})$ were directly proportional to the cell seeding densities as oxidation peak current values increased with increasing cell numbers. A slight anodic shift of the oxidation peak potential was observed $(\sim+0.4 \mathrm{~V})$ while monitoring cellular 1-naphthol generation compared to the $1-\mathrm{NpOH}$ standards (neat product, $+0.35 \mathrm{~V}$ ). This is acceptable and likely due to residual protein content from the tissue culture medium which may affect the sensor surface and hence the performance. Printed carbon surfaces are known to be susceptible to protein fouling due to surface roughness and morphology features. ${ }^{49}$

A small background current $(362.83 \pm 8.97 \mathrm{nA})$ was also observed in the case of cell-free culture medium (control including substrate at room temperature, $2 \mathrm{~h}$, Figure 3D), which is higher than the previously observed substrate current response of the order of $\sim 100 \mathrm{nA}$ ( $2 \mathrm{~h}$, room temperature), suggesting additional hydrolysis of the substrate due to possible residual activity of the cell culture medium. The 96 well plates used in this study comprise tissue culture-treated flat bottoms to promote cell adhesion. The tissue culture treatment process involves exposing the polystyrene to vacuum-gas plasma to modify the hydrophobic plastic surface into a more hydrophilic surface. The resulting surface carries a net negative charge because of the oxygen-containing functional groups such as $-\mathrm{OH}$ and $-\mathrm{COOH}$. These groups aid 

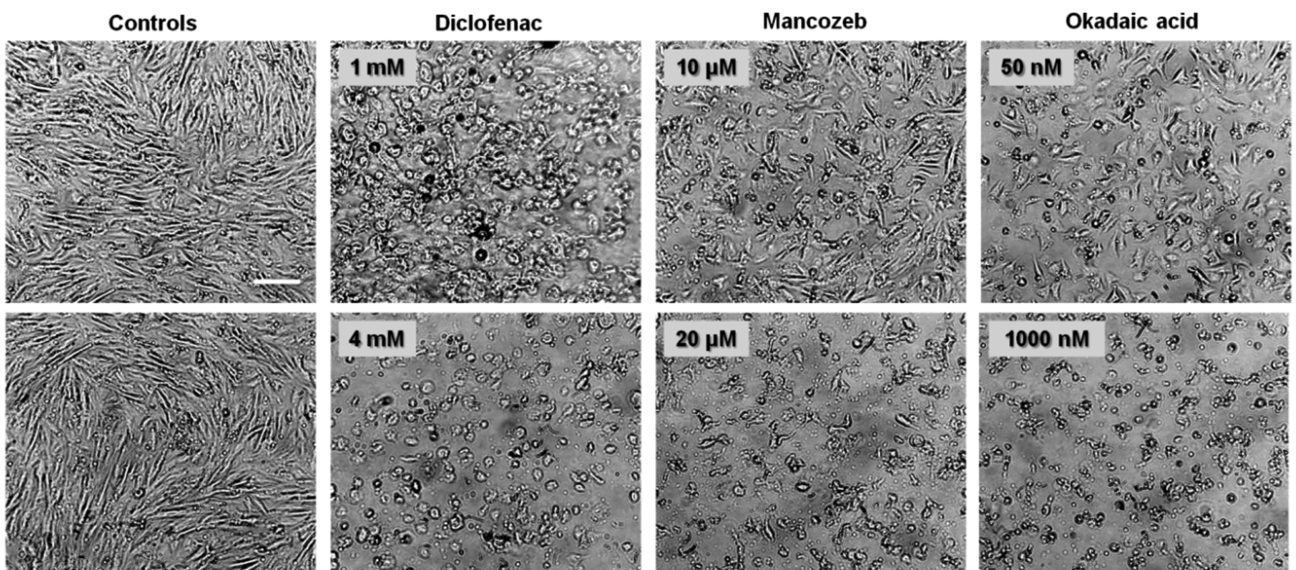

Figure 4. Representative morphology of the $2 \mathrm{D}$ monolayers of intestinal cells at intermediate-dose and high-dose treatments of diclofenac, mancozeb, and okadaic acid, along with untreated controls, respectively. Scale bar represents $100 \mu \mathrm{m}$.

A
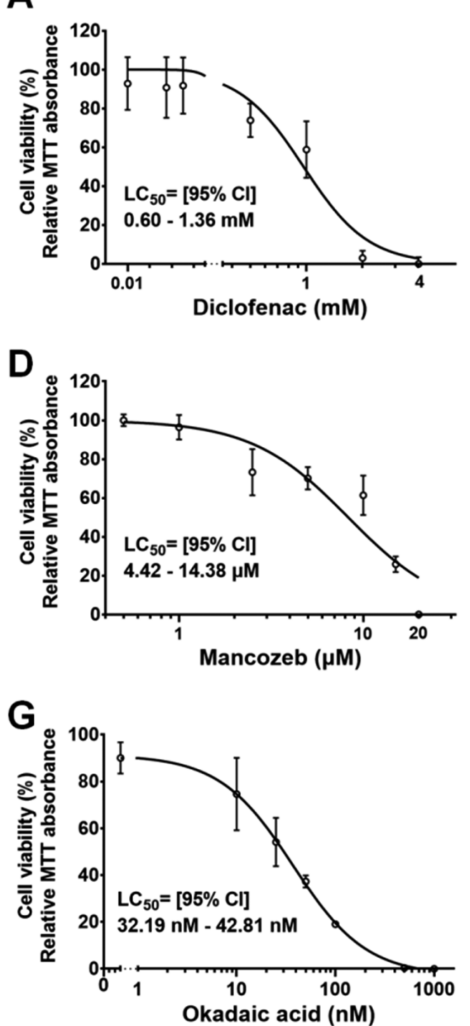
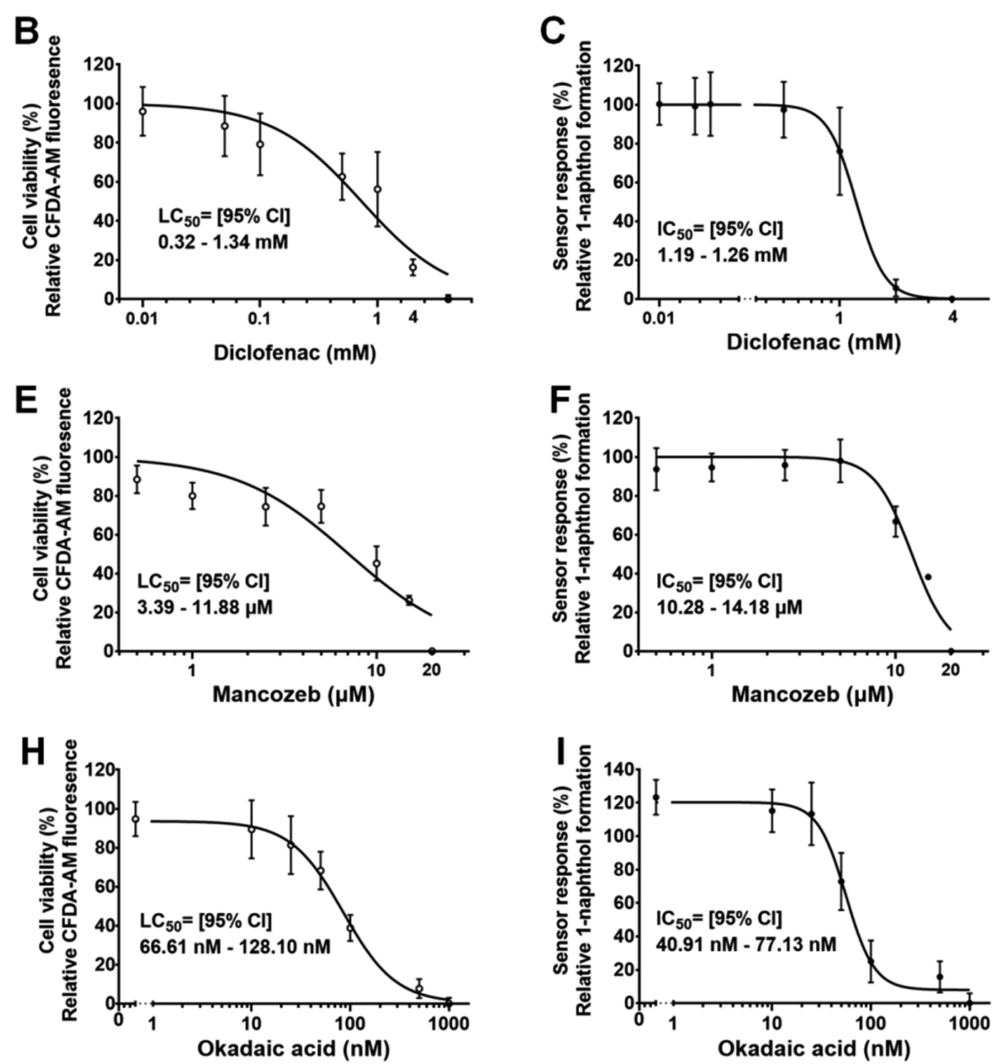

Figure 5. Dose-response curves for 2D intestinal xenobiotic exposure on the inhibition of cell viability based on the MTT (A, D, G) and CFDA$\mathrm{AM}(\mathrm{B}, \mathrm{E}, \mathrm{H})$ assays and normalized sensor response (C, F, I) fitted by nonlinear regression.

the adhesion of proteins/enzymes from the fetal bovine serum supplement of the cell culture medium. According to the literature, fetal bovine serum contains esterase enzymes ${ }^{44,45}$ and could be responsible for the 1-naphthol detection on the cell free samples. This response, however, can be considered negligible, as it is significantly different compared to all the studied cell populations at the $99.9 \%$ confidence level (oneway ANOVA, Dunnett's test, ${ }^{* * *} p \leq 0.001$ vs control, Figure 3D).

Considering 1-naphthol's fluorescence properties, its cellular generation was also investigated fluorometrically. As shown in Figure 3E, the fluorescence intensities of successively increasing cell populations, at the emission max of 1-naphthol $\left(\lambda_{\mathrm{em}} \sim 460 \mathrm{~nm}\right),{ }^{50}$ after incubation with 1-NA, showed a strong positive correlation with cell numbers, without any statistically significant difference when comparing the control (no cells) with the lowest cell population $\left(5 \times 10^{3}\right.$ cells, $p=$ $0.48>0.05$ vs control, Figure $3 \mathrm{E}$ ), suggesting that the electrochemical approach could be more sensitive for low cell numbers. Further, nonspecific esterase of cells was also evaluated using the CFDA-AM assay (Figure 3F). The fluorogenic dye CFDA is a viability probe that measures cellmembrane integrity through enzymatic activity. This membrane permeable, nonpolar, nonfluorescent substance can be converted by nonspecific esterases of living cells into a polar, fluorescent dye, carboxyfluorescein (CF). The conversion to 

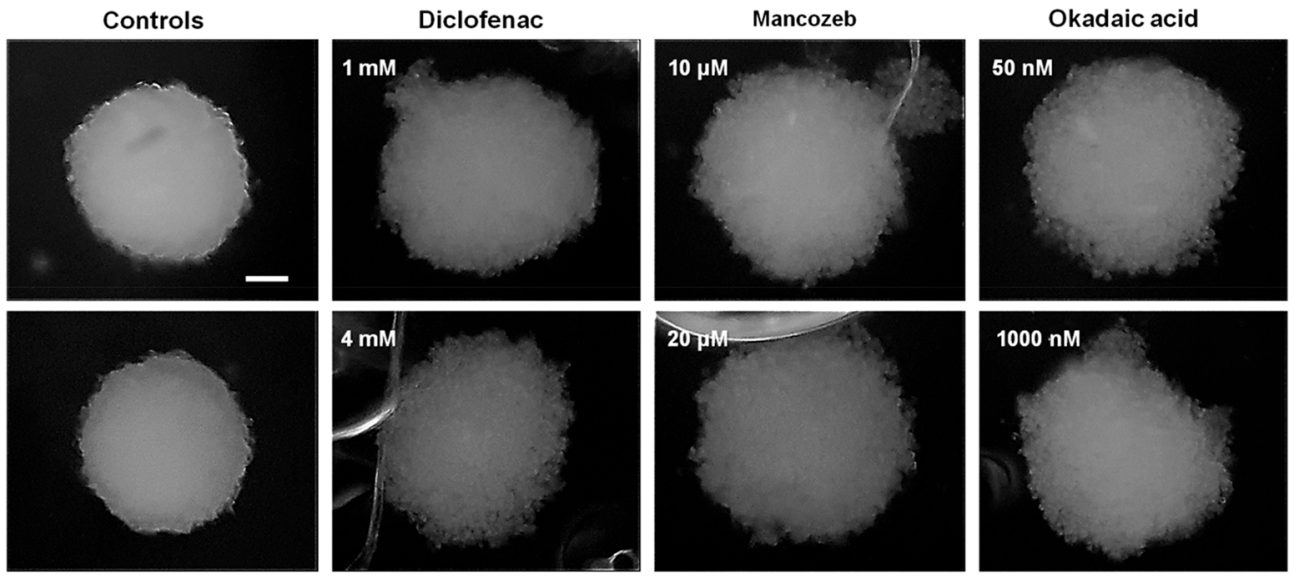

Figure 6. Representative morphology of the 3D intestinal spheroids at intermediate-dose and high-dose treatments of diclofenac, mancozeb, and okadaic acid, along with untreated controls, respectively. Images were recorded using an inverted microscope in integrated modulation contrast (IMC) mode; scale bar represents $100 \mu \mathrm{m}$.

CF by the cells indicates the integrity of the cell membrane (plasma membrane or cytoplasmic membrane), since only an intact membrane can maintain the cytoplasmic milieu which is needed to support esterase activity. ${ }^{51}$ When plotted against cell numbers, CF fluorescence intensities showed a strong positive correlation with cell numbers, without any statistically significant difference between the control (no cells) with the lowest cell population $\left(5 \times 10^{3}\right.$ cells, $p=0.28>0.05$ vs control, Figure $3 \mathrm{~F}$ ), suggesting that the electrochemical approach could be more sensitive for low cell numbers.

Electrochemical Cytotoxicity Assessment and Viability Analysis. After establishing a correlation between cell number and electrochemical response, the nonsteroidal antiinflammatory drug diclofenac, the diarrheic shellfish poisoning toxin okadaic acid, and the ethylene bisdithiocarbamate fungicide mancozeb, all widely studied for their adverse effects on the gastrointestinal tract, were selected as models to assess the ability of the proposed assay to monitor intestinal cell viability.

To study the effect of the above xenobiotics on the intestinal viability (MTT, CFDA-AM) and sensor response (1-NpOH electrochemical detection), cell monolayers and spheroids were treated with different concentrations of each substance for $24 \mathrm{~h}$. MTT assay is one of the most widely used cytotoxicity/cell proliferation assays; the yellow tetrazolium salt MTT is reduced by mitochondrial dehydrogenases of living cells to blue formazan crystals, giving an indirect measure of cell metabolism. CFDA-AM, as discussed earlier, is also an established viability/cytotoxicity probe. At the end of the exposure period, the toxin-containing culture medium was aspirated; cells or spheroids were gently washed with PBS and subsequently incubated with MTT, CFDA-AM, and 1-NA for 4, 1, and $2 \mathrm{~h}$, respectively. At the end of the incubation, viability was assayed optically, fluorometrically, and microscopically, while CVs were recorded as described previously. Data from all three assays were plotted against applied doses and fitted to sigmoidal curves as shown in Figure 5 and Figure 7, while morphology observations are presented in Figure 4 and Figure 6.

Xenobiotic exposure resulted in a dose-dependent decrease in MTT absorbance, CFDA-AM fluorescence intensity, electrochemical response, and morphology alterations for all three tested substances in both $2 \mathrm{D}$ and $3 \mathrm{D}$ culture formats.
In the case of $2 \mathrm{D}$ culture format, maximal cytotoxic effects were observed at concentrations over $2 \mathrm{mM}$ for the DCF, 20 $\mu \mathrm{M}$ for $\mathrm{MZB}$, and $500 \mathrm{nM}$ for $\mathrm{OA}$ for all three assays. Microscopy observations of the exposed monolayer cultures showed clear signals of cytotoxicity with increasing concentrations of the xenobiotics. Treated cells suffered by morphological modifications such as rounding up and detaching from the substrate, cell aggregation, swell/shrink perturbations, blebbing, or cell lysis (Figure 4).

Dose response sigmoidal curve fitting (Figure 5) for MTT indicated median lethal concentrations $\left(\mathrm{LC}_{50}\right)$ of $0.60-1.36$ $\mathrm{mM}(95 \% \mathrm{CI})$ for DCF, 4.42-14.38 $\mu \mathrm{M}(95 \% \mathrm{CI})$ for MZB, and $32.19-42.81 \mathrm{nM}(95 \% \mathrm{CI})$ for OA, respectively. CFDA$\mathrm{AM} \mathrm{LC}_{50}$ values ranged from 0.32 to $1.34 \mathrm{mM}(95 \% \mathrm{CI})$ for DCF, 3.39-11.88 $\mu \mathrm{M}$ (95\% CI) for MZB, and 66.61-128.10 $\mathrm{nM}(95 \% \mathrm{CI})$ for OA, respectively. Finally, sensor $\mathrm{IC}_{50}$ values (median inhibitory concentrations) were calculated at 1.19$1.26 \mathrm{mM}$ (95\% CI) for DCF, 10.28-14.18 $\mu \mathrm{M}$ (95\% CI) for $\mathrm{MZB}$, and 40.91-77.13 nM (95\% CI) for OA, respectively. All sensor $\mathrm{IC}_{50}$ values were found within the same concentration range $(95 \% \mathrm{CI})$ with the $\mathrm{LC}_{50}$ values of the conventional viability assays (MTT and CFDA-AM) indicating that the results of the proposed electrochemical assay are a strong indication of cytotoxicity in monolayer cultures.

Similar to the 2D data obtained in this study, previous studies on DCF cytotoxicity on monolayer cultures have reported $\mathrm{LC}_{50}$ values of $\sim 0.68 \mathrm{mM}$ for hepatoma cells, ${ }^{52} \sim 0.5$ $\mathrm{mM}$ for canine kidney cells, ${ }^{53}$ and $0.8 \mathrm{mM}$ for human donor hepatocytes. ${ }^{54}$ DCF toxicity data on intestinal cell lines are scarce; however, studies on cytotoxicity of DCF in human precision-cut intestinal slices report significant toxicity above $0.4 \mathrm{mM}^{55}$ comparable with all three assays of the present study. Literature data on MZB gastrointestinal cytotoxicity report a 54\% decreased survival rate of human gastric NSU-1 cells after $24 \mathrm{~h}$ exposure to $10 \mu \mathrm{M} \mathrm{MZB}$, results also in concert with the data of the present study. Other investigators have reported MZB toxicity in transformed colon (large intestine) cells with $\mathrm{LC}_{50}$ values ranging from $40 \mu \mathrm{M}$ to $180 \mu \mathrm{M}{ }^{43}$ results notably higher than our observed data. This disparity could be attributed to the fact that colon cells have been demonstrated to be more resistant to pesticide exposure when compared to other cell types. ${ }^{56}$ Finally, OA exposure on intestinal cells has been reported to result $\mathrm{LC}_{50}$ values of 
A

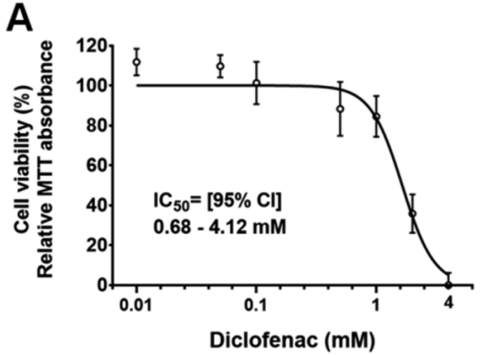

D

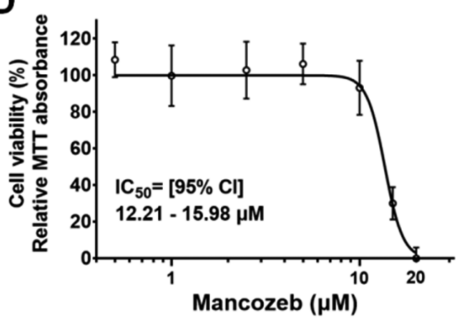

G

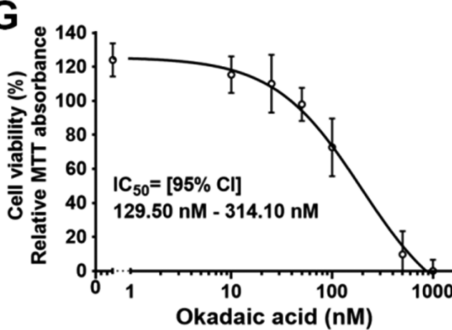

B

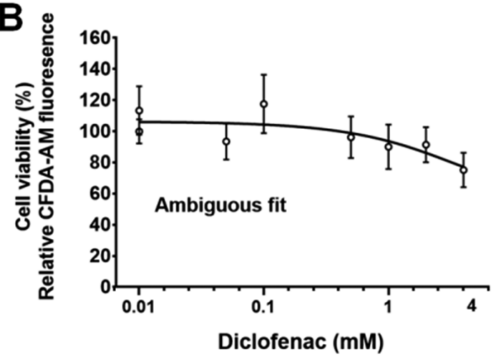

E
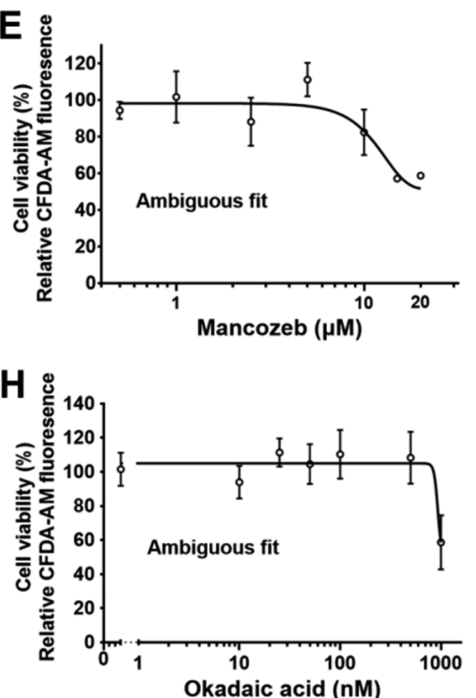

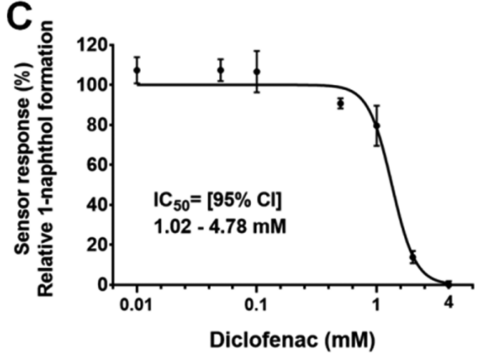

$\mathbf{F}_{\text {。 }}$
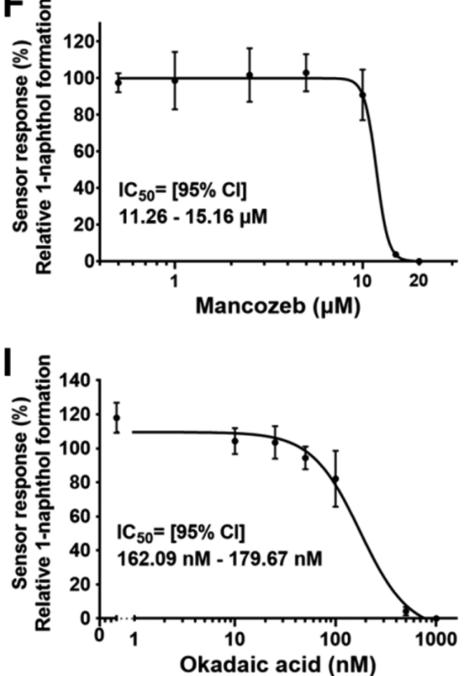

Figure 7. Dose-response curves for 3D intestinal xenobiotic exposure on the inhibition of cell viability based on the MTT (A, D, G) and CFDAAM (B, E, H) assays and normalized sensor response (C, F, I) fitted by nonlinear regression.

16.59-82.75 nM (95\% CI) for Caco-2 human colon cells, ${ }^{57}$ in close range with the $95 \% \mathrm{CI}$ results of all three assays of the present study.

In the case of $3 \mathrm{D}$ culture format, spheroid toxicity was observed morphologically under an inverted microscope in integrated modulation contrast (IMC) mode. The spheroids were generated using pellet culture on low attachment Ushaped microplates, which along with the hanging drop $\operatorname{method}^{58,59}$ allow for more precise control of spheroid size and high-throughput formats. Other methods for spheroid generation include the spinner culture method, the rotating wall vessel, and the electric/magnetic force, which have high yields but the produced spheroids often vary in both size and shape. $^{60}$

As shown in Figure 6, control spheroids are characterized by rounded, smooth surfaces without clearly defined individual cells, while treated ones exhibit a rippled, rough surface with clearly defined individual cells, phenotypic changes typical of toxicity. ${ }^{61}$ The overall morphology of the untreated spheroids shows compact formations, contrary to the disintegrated, "loosened up" structures of the treated ones.

When comparing the viability results of the $2 \mathrm{D}$ cell culture format (Figure 5) with the 3D format (Figure 7), we observed a shift of the $\mathrm{LC}_{50}$ and $\mathrm{IC}_{50}$ values to higher concentration ranges $(95 \% \mathrm{CI})$ for all three xenobiotics. Dose response sigmoidal curve fitting of the MTT (Figure 7A,D,G) indicated $\mathrm{LC}_{50 \mathrm{~s}}$ of $0.68-4.12 \mathrm{mM}$ (95\% CI) for DCF, 12.21-15.98 $\mu \mathrm{M}$ (95\% CI) for MZB, and $129.50-314.10 \mathrm{nM}$ (95\% CI) for OA, respectively. Sigmoidal curve fitting of the sensor $3 \mathrm{D}$ results indicated $\mathrm{IC}_{50}$ values of $1.02-4.78 \mathrm{mM}(95 \% \mathrm{CI})$ for DCF, $11.26-15.16 \mu \mathrm{M}(95 \% \mathrm{CI})$ for MZB, and 162.09-179.67 nM
(95\% CI) for OA, respectively. CFDA-AM was unable to resolve differences in any compound (Figure 7B,E,H), suggesting that the CFDA-AM microplate method is insufficient in assaying $3 \mathrm{D}$ spheroids compared to $2 \mathrm{D}$ monolayers, potentially due to depth-dependent light scattering obstruction, that attenuates fluorescence excitation and emission intensity ${ }^{61}$ in the case of formations like spheroids. This limitation, however, does not seem to affect the optical MTT assay, possibly because of the final solvent lysis step (DMSO) that is employed before the absorbance readings. Similarly, the addition of the detergent Triton X-100, in the case of the proposed electrochemical sensor, allowed the permeabilization of the cells and the release of the end-product from the cytosol. Triton X-100 is known to effectively permeabilize mammalian cells for cellular enzyme activity measurements, ${ }^{62}$ without damaging cellular structure. All sensor $3 \mathrm{D} \mathrm{IC}_{50}$ values (Figure $7 \mathrm{C}, \mathrm{F}, \mathrm{I}$ ) were found within the same concentration range $\left(95 \% \mathrm{CI}\right.$ ) with the $\mathrm{LC}_{50}$ values of the conventional MTT assays indicating that the proposed electrochemical assay can reflect cytotoxicity in 3D culture format.

The results of both the conventional viability and sensor assays employed in the present work show that, unlike their $2 \mathrm{D}$ counterparts, 3D cultures of HIEC-6 were less susceptible to lower concentrations of the toxicants. Those results were expected and consistent with numerous literature reports on 3D toxicological studies, ${ }^{63-65}$ as $3 \mathrm{D}$ cultures bear an additional dimension of cell to cell and cell to extracellular matrix contact which improves the viability of their systems. ${ }^{66}$ A known limitation of using 2D culture systems for toxicological studies is that they could lead to overestimation of toxicity as a 
consequence of the absence of $3 \mathrm{D}$ cell organization. When subjected to xenobiotic exposure, $3 \mathrm{D}$ spheroids are reported to have the ability to impair the diffusion of the toxicant to their core, as the cells on their outer layers provide a natural barrier. Additionally, spheroid formation is known to enhance drug efflux activities, ${ }^{67}$ which affects their drug resistance, mimicking in vivo conditions. The proposed sensor was able to detect the enhanced xenobiotic resistance of cells in 3D architecture as indicated by the increased $3 \mathrm{D} \mathrm{IC}_{50}$ values compared with the $2 \mathrm{D}$ ones. Similar results on $3 \mathrm{D}$ over $2 \mathrm{D}$ toxicity resistance have been reported in other bioassay development studies on mouse embryonic fibroblasts, ${ }^{68}$ human hepatoma cells, ${ }^{65}$ human neuroblastoma, and glioblastoma cells. ${ }^{69}$

\section{CONCLUSION}

Sensors that assess cellular cytotoxic responses have been exploited for a broad range of applications. The use of mammalian cells in biosensors can provide responses relevant to human physiology. Of the various toxicity sensors that have been proposed, however, there are few studies adopting electrochemical sensors to evaluate both $2 \mathrm{D}$ and $3 \mathrm{D}$ cell culture formats. In this study, we developed an electrochemical assay for cell viability/toxicity measurements based on the enzymatic activity of nonspecific esterase of healthy, intact cells. Based on this enzyme based biosensor, it is convenient to measure the viability of both $2 \mathrm{D}$ and $3 \mathrm{D}$ cell culture formats and provide more dynamic data for drug/toxicity screening. The proposed biosensor showed a high consistency with the conventional cell viability assays applied in this work and relevant literature. All sensor $\mathrm{IC}_{50}$ values were found within the same concentration range $(95 \% \mathrm{CI})$ with the $\mathrm{LC}_{50}$ values of the conventional viability assays indicating that the results of the proposed electrochemical assay are a good indication for cytotoxicity in both $2 \mathrm{D}$ and $3 \mathrm{D}$ culture formats. The resulting assay offers a simple and robust endpoint cytotoxicity screening in $2 \mathrm{D}$ and $3 \mathrm{D}$ architecture. Further work will focus on investigating additional cell types and 3D architectures, sensor surface modifying/improving techniques, substrate molecules and on minimizing substrate incubation time.

\section{ASSOCIATED CONTENT}

\section{S Supporting Information}

The Supporting Information is available free of charge on the ACS Publications website at DOI: 10.1021/acssensors.8b01490.

Material and reagents; MTT assay; CFDA-AM assay (PDF)

\section{AUTHOR INFORMATION}

\section{Corresponding Author}

*E-mail: Baljit.Singh@ittdublin.ie. Tel: +353 1404 2033. Fax: +35314042753.

\section{ORCID}

Evangelia Flampouri: 0000-0003-2121-4414

Shahzad Imar: 0000-0003-1501-8943

Baljit Singh: 0000-0002-0871-883X

\section{Notes}

The authors declare no competing financial interest.

\section{ACKNOWLEDGMENTS}

Dr. Baljit Singh thanks and acknowledges Enterprise Ireland and European Regional Development Fund 2014-2020 Programme (ERDF, European Union) for provision of financial support. MiCRA Biodiagnostics is funded under the Enterprise Ireland Technology Gateway Programme (Grant Number: TG20171013).

\section{REFERENCES}

(1) Barlow, S. M.; Greig, J. B.; Bridges, J. W.; Carere, A.; Carpy, A. J. M.; Galli, C. L.; Kleiner, J.; Knudsen, I.; Koëter, H. B. W. M.; Levy, L. S.; et al. Hazard Identification by Methods of Animal-Based Toxicology. Food Chem. Toxicol. 2002, 40 (2-3), 145-191.

(2) Baumans, V. Use of Animals in Experimental Research: An Ethical Dilemma? Gene Ther. 2004, 11, S64-S66.

(3) Sharma, K.; Arora, T.; Joshi, V.; Rathor, N.; Mehta, A.; Mehta, K.; Mediratta, P. Substitute of Animals in Drug Research: An Approach towards Fulfillment of 4R's. Indian J. Pharm. Sci. 2011, 73 (1), 1 .

(4) Guhad, F. Introduction to the 3Rs (Refinement, Reduction and Replacement). J. Am. Assoc. Lab. Anim. Sci. 2005, 44 (2), 58-59.

(5) Yang; Wang; Zang; Tang; Li. Cell-Based Assays in HighThroughput Screening for Drug Discovery. Int. J. Biotechnol. Wellness Ind. 2012.; DOI: 10.6000/1927-3037.2012.01.01.02

(6) Poteser, M. Cell-Based in Vitro Models in Environmental Toxicology: A Review. Biomonitoring 2017, 4 (1), 11-26.

(7) Edmondson, R.; Broglie, J. J.; Adcock, A. F.; Yang, L. ThreeDimensional Cell Culture Systems and Their Applications in Drug Discovery and Cell-Based Biosensors. Assay Drug Dev. Technol. 2014, 12 (4), 207-218.

(8) Langhans, S. A. Three-Dimensional in Vitro Cell Culture Models in Drug Discovery and Drug Repositioning. Front. Pharmacol. 2018; DOI: $10.3389 /$ fphar.2018.00006

(9) Thoma, C. R.; Zimmermann, M.; Agarkova, I.; Kelm, J. M.; Krek, W. 3D Cell Culture Systems Modeling Tumor Growth Determinants in Cancer Target Discovery. Adv. Drug Delivery Rev. 2014, 69-70, 29-41.

(10) Selden, C.; Khalil, M.; Hodgson, H. Three Dimensional Culture Upregulates Extracellular Matrix Protein Expression in Human Liver Cell Lines - A Step towards Mimicking the Liver in Vivo? Int. J. Artif. Organs 2000, 23 (11), 774-781.

(11) Griffith, L. G.; Swartz, M. A. Capturing Complex 3D Tissue Physiology in Vitro. Nat. Rev. Mol. Cell Biol. 2006, 7, 211-224.

(12) Pampaloni, F.; Reynaud, E. G.; Stelzer, E. H. K. The Third Dimension Bridges the Gap between Cell Culture and Live Tissue. Nat. Rev. Mol. Cell Biol. 2007, 8, 839.

(13) Carlsson, J.; Nilsson, K.; Westermark, B.; Pontén, J.; Sundström, C.; Larsson, E.; Bergh, J.; Påhlman, S.; Busch, C.; Collins, V. P. Formation and Growth of Multicellular Spheroids of Human Origin. Int. J. Cancer 1983, 31 (5), 523-533.

(14) Mueller-Klieser, W. Multicellular Spheroids - A Review on Cellular Aggregates in Cancer Research. J. Cancer Res. Clin. Oncol. 1987, 113, 101-122.

(15) Fang, Y.; Eglen, R. M. Three-Dimensional Cell Cultures in Drug Discovery and Development. SLAS Discovery. SAGE Publications 2017, 22, 456-472.

(16) Zanoni, M.; Piccinini, F.; Arienti, C.; Zamagni, A.; Santi, S.; Polico, R.; Bevilacqua, A.; Tesei, A. 3D Tumor Spheroid Models for in Vitro Therapeutic Screening: A Systematic Approach to Enhance the Biological Relevance of Data Obtained. Sci. Rep. 2016, 6, 1 DOI: $10.1038 /$ srep 19103.

(17) Tostões, R. M.; Leite, S. B.; Serra, M.; Jensen, J.; Björquist, P.; Carrondo, M. J. T.; Brito, C.; Alves, P. M. Human Liver Cell Spheroids in Extended Perfusion Bioreactor Culture for RepeatedDose Drug Testing. Hepatology 2012, 55 (4), 1227-1236.

(18) Hendriks, D. F. G.; Puigvert, L. F.; Messner, S.; Mortiz, W.; Ingelman-Sundberg, M. Hepatic 3D Spheroid Models for the 
Detection and Study of Compounds with Cholestatic Liability. Sci. Rep. 2016, 6, 1 DOI: 10.1038/srep35434.

(19) Rescigno, M. Intestinal Epithelial Spheroids: New Tools for Studying Gastrointestinal Diseases. Gut 2015, 64, 859-860.

(20) VanDussen, K. L.; Marinshaw, J. M.; Shaikh, N.; Miyoshi, H.; Moon, C.; Tarr, P. I.; Ciorba, M. A.; Stappenbeck, T. S. Development of an Enhanced Human Gastrointestinal Epithelial Culture System to Facilitate Patient-Based Assays. Gut 2015, 64 (6), 911-920.

(21) Laschke, M. W.; Menger, M. D. Life Is 3D: Boosting Spheroid Function for Tissue Engineering. Trends Biotechnol. 2017, 35, 133144.

(22) Sart, S.; Tsai, A.-C.; Li, Y.; Ma, T. Three-Dimensional Aggregates of Mesenchymal Stem Cells: Cellular Mechanisms, Biological Properties, and Applications. Tissue Eng., Part B 2014, 20 (5), 365-380.

(23) Stoddart, M. J. Cell Viability Assays: Introduction. Methods Mol. Biol. (N. Y., NY, U. S.) 2011, 740, 1-6.

(24) Niles, A. L.; Moravec, R. A.; Riss, T. L. Update on in Vitro Cytotoxicity Assays for Drug Development. Expert Opin. Drug Discovery 2008, 3 (6), 655-669.

(25) Sali, N.; Nagy, S.; Poór, M.; Koszegi, T. Multiparametric Luminescent Cell Viability Assay in Toxicology Models: A Critical Evaluation. J. Pharmacol. Toxicol. Methods 2016, 79, 45-54.

(26) Haugland, R. P. Section 15.2. Molecular Probes. In Handbook of fluorescent probes and research chemicals; 2006.

(27) Bruggisser, R.; Von Daeniken, K.; Jundt, G.; Schaffner, W.; Tullberg-Reinert, H. Interference of Plant Extracts, Phytoestrogens and Antioxidants with the MTT Tetrazolium Assay. Planta Med. 2002, 68 (5), 445-448.

(28) Blockhuys, S.; Vanhoecke, B.; Smet, J.; De Paepe, B.; Van Coster, R.; Bracke, M.; De Wagter, C. Unraveling the Mechanisms Behind the Enhanced MTT Conversion by Irradiated Breast Cancer Cells. Radiat. Res. 2013, 179 (4), 433-443.

(29) Stepanenko, A. A.; Dmitrenko, V. V. Pitfalls of the MTT Assay: Direct and off-Target Effects of Inhibitors Can Result in over/ Underestimation of Cell Viability. Gene 2015, 574 (2), 193-203.

(30) Qin, H.; Liu, J.; Zhang, Z.; Li, J.; Gao, G.; Yang, Y.; Yuan, X.; $\mathrm{Wu}, \mathrm{D}$. In Situ Electrochemical Assessment of Cytotoxicity of Chlorophenols in MCF-7 and HeLa Cells. Anal. Biochem. 2014, 462, 60-66.

(31) Zhu, X.; Wu, G.; Lu, N.; Yuan, X.; Li, B. A Miniaturized Electrochemical Toxicity Biosensor Based on Graphene Oxide Quantum Dots/Carboxylated Carbon Nanotubes for Assessment of Priority Pollutants. J. Hazard. Mater. 2017, 324, 272-280.

(32) Biosensors-A Global Market Overview; Industry Experts, 2017, Report Code: BT012 (Pages: 280).

(33) Ding, L.; Du, D.; Zhang, X.; Ju, H. Trends in Cell-Based Electrochemical Biosensors. Curr. Med. Chem. 2008, 15 (30), 31603170.

(34) Thummel, K. E. Gut Instincts: CYP3A4 and Intestinal Drug Metabolism. J. Clin. Invest. 2007, 117, 3173-3176.

(35) Orbach, S. M.; Less, R. R.; Kothari, A.; Rajagopalan, P. In Vitro Intestinal and Liver Models for Toxicity Testing. ACS Biomater. Sci. Eng. 2017, 3, 1898-1910.

(36) Zhu, Y.; Zhang, Q.-Y. Role of Intestinal Cytochrome P450 Enzymes in Diclofenac-Induced Toxicity in the Small Intestine. J. Pharmacol. Exp. Ther. 2012, 343 (2), 362-370.

(37) Valdiglesias, V.; Prego-Faraldo, M. V.; Paśaro, E.; Meńdez, J.; Laffon, B. Okadaic Acid: More than a Diarrheic Toxin. Mar. Drugs 2013, 11, 4328-4349.

(38) Hoffman, L.; Trombetta, L.; Hardej, D. Ethylene Bisdithiocarbamate Pesticides Maneb and Mancozeb Cause Metal Overload in Human Colon Cells. Environ. Toxicol. Pharmacol. 2016, 41, 78-88.

(39) Davies, N. M.; Saleh, J. Y.; Skjodt, N. M. Detection and Prevention of NSAID-Induced Enteropathy. J. Pharm. Pharmaceutical Sci. 2000, 137-155.

(40) Ramirez-Alcantara, V.; LoGuidice, A.; Boelsterli, U. A. Protection from Diclofenac-Induced Small Intestinal Injury by the JNK Inhibitor SP600125 in a Mouse Model of NSAID-Associated
Enteropathy. Am. J. Physiol. Gastrointest. Liver Physiol. 2009, 297 (5), G990-8.

(41) Yasumoto, T.; Murata, M.; Oshima, Y.; Sano, M.; Matsumoto, G. K.; Clardy, J. Diarrhetic Shellfish Toxins. Tetrahedron 1985, 41 (6), 1019-1025.

(42) Matias, W. G.; Traore, A.; Creppy, E. E. Variations in the Distribution of Okadaic Acid in Organs and Biological Fluids of Mice Related to Diarrhoeic Syndrome. Hum. Exp. Toxicol. 1999, 18 (5), $345-350$.

(43) Hoffman, L.; Hardej, D. Ethylene Bisdithiocarbamate Pesticides Cause Cytotoxicity in Transformed and Normal Human Colon Cells. Environ. Toxicol. Pharmacol. 2012, 34 (2), 556-573.

(44) Phung, Y. T.; Barbone, D.; Broaddus, V. C.; Ho, M. Rapid Generation of in Vitro Multicellular Spheroids for the Study of Monoclonal Antibody Therapy. J. Cancer 2011, 2 (1), 507-514.

(45) Däster, S.; Amatruda, N.; Calabrese, D.; Ivanek, R.; Turrini, E.; Droeser, R. A.; Zajac, P.; Fimognari, C.; Spagnoli, G. C.; Iezzi, G.; et al. Induction of Hypoxia and Necrosis in Multicellular Tumor Spheroids Is Associated with Resistance to Chemotherapy Treatment. Oncotarget 2017, 8 (1), 1725-1736.

(46) Mosmann, T. Rapid Colorimetric Assay for Cellular Growth and Survival: Application to Proliferation and Cytotoxicity Assays. J. Immunol. Methods 1983, 65 (1-2), 55-63.

(47) Ganassin, R. C.; Schirmer, K.; Bols, N. C. Cell and Tissue Culture. In The Laboratory Fish; Academic Press, 2000; pp 631-651; DOI: 10.1016/B978-012529650-2/50047-0.

(48) Shrivastava, A.; Gupta, V. Methods for the Determination of Limit of Detection and Limit of Quantitation of the Analytical Methods. Chronicles Young Sci. 2011, 2 (1), 21.

(49) Kissinger, P.; Heineman, W. R. Laboratory Techniques in Electroanalytical Chemistry, 2nd ed., CRC Press, 1996; p 1008.

(50) Kumar, A. C.; Mishra, A. K. 1-Naphthol as an Excited State Proton Transfer Fluorescent Probe for Sensing Bound-Water Hydration of Polyvinyl Alcohol. Talanta 2007, 71 (5), 2003-2006.

(51) Schirmer, K.; Chan, A. G. J.; Greenberg, B. M.; Dixon, D. G.; Bols, N. C. Methodology for Demonstrating and Measuring the Photocytotoxicity of Fluoranthene to Fish Cells in Culture. Toxicol. In Vitro 1997, 11 (1-2), 107-119.

(52) Bort, R.; Ponsoda, X.; Jover, R.; Gómez-Lechón, M. J.; Castell, J. V. Diclofenac Toxicity to Hepatocytes: A Role for Drug Metabolism in Cell Toxicity. J. Pharmacol. Exp. Ther. 1999, 288 (1), 65-72.

(53) Ng, L. E.; Halliwell, B.; Wong, K. P. Nephrotoxic Cell Death by Diclofenac and Meloxicam. Biochem. Biophys. Res. Commun. 2008, 369 (3), 873-877.

(54) Al-Attrache, H.; Sharanek, A.; Burban, A.; Burbank, M.; Gicquel, T.; Abdel-Razzak, Z.; Guguen-Guillouzo, C.; Morel, I.; Guillouzo, A. Differential Sensitivity of Metabolically Competent and Non-Competent HepaRG Cells to Apoptosis Induced by Diclofenac Combined or Not with TNF- $\alpha$. Toxicol. Lett. 2016, 258, 71-86.

(55) Niu, X.; de Graaf, I. A. M.; Langelaar-Makkinje, M.; Horvatovich, P.; Groothuis, G. M. M. Diclofenac Toxicity in Human Intestine Ex Vivo Is Not Related to the Formation of Intestinal Metabolites. Arch. Toxicol. 2015, 89 (1), 107-119.

(56) Vidau, C.; Brunet, J. L.; Badiou, A.; Belzunces, L. P. Phenylpyrazole Insecticides Induce Cytotoxicity by Altering Mechanisms Involved in Cellular Energy Supply in the Human Epithelial Cell Model Caco-2. Toxicol. In Vitro 2009, 23 (4), 589-597.

(57) Ferron, P. J.; Hogeveen, K.; Fessard, V.; Le Hégarat, L. Comparative Analysis of the Cytotoxic Effects of Okadaic Acid-Group Toxins on Human Intestinal Cell Lines. Mar. Drugs 2014, 12 (8), 4616-4634.

(58) Ong, C. S.; Zhou, X.; Han, J.; Huang, C. Y.; Nashed, A.; Khatri, S.; Mattson, G.; Fukunishi, T.; Zhang, H.; Hibino, N. In Vivo Therapeutic Applications of Cell Spheroids. Biotechnol. Adv. 2018, 36 (2), 494-505.

(59) Shin, D.-S.; Seo, H.; Yang, J. Y.; Joo, J.; Im, S. H.; Kim, S. S.; Kim, S. K.; Bae, M. A. Quantitative Evaluation of Cytochrome P450 3A4 Inhibition and Hepatotoxicity in HepaRG 3-D Spheroids. Int. J. Toxicol. 2018, 37 (5), 393-403. 
(60) Achilli, T.-M.; Meyer, J.; Morgan, J. R. Advances in the Formation, Use and Understanding of Multi-Cellular Spheroids. Expert Opin. Biol. Ther. 2012, 12 (10), 1347-1360.

(61) Sirenko, O.; Hancock, M. K.; Hesley, J.; Hong, D.; Cohen, A.; Gentry, J.; Carlson, C. B.; Mann, D. A. Phenotypic Characterization of Toxic Compound Effects on Liver Spheroids Derived from IPSC Using Confocal Imaging and Three-Dimensional Image Analysis. Assay Drug Dev. Technol. 2016, 14 (7), 381-394.

(62) Niklas, J.; Melnyk, A.; Yuan, Y.; Heinzle, E. Selective Permeabilization for the High-Throughput Measurement of Compartmented Enzyme Activities in Mammalian Cells. Anal. Biochem. 2011, 416 (2), 218-227.

(63) Bokhari, M.; Carnachan, R. J.; Cameron, N. R.; Przyborski, S. A. Culture of HepG2 Liver Cells on Three Dimensional Polystyrene Scaffolds Enhances Cell Structure and Function during Toxicological Challenge. J. Anat. 2007, 211 (4), 567-576.

(64) Oshikata, A.; Matsushita, T.; Ueoka, R. Enhancement of Drug Efflux Activity via MDR1 Protein by Spheroid Culture of Human Hepatic Cancer Cells. J. Biosci. Bioeng. 2011, 111 (5), 590-593.

(65) Zhao, S. P.; Ma, Y.; Lou, Q.; Zhu, H.; Yang, B.; Fang, Q. ThreeDimensional Cell Culture and Drug Testing in a Microfluidic Sidewall-Attached Droplet Array. Anal. Chem. 2017, 89 (19), 1015310157.

(66) Yip, D.; Cho, C. H. A Multicellular 3D Heterospheroid Model of Liver Tumor and Stromal Cells in Collagen Gel for Anti-Cancer Drug Testing. Biochem. Biophys. Res. Commun. 2013, 433 (3), 327332.

(67) Oshikata, A.; Matsushita, T.; Ueoka, R. Enhancement of Drug Efflux Activity via MDR1 Protein by Spheroid Culture of Human Hepatic Cancer Cells. J. Biosci. Bioeng. 2011, 111 (5), 590-593.

(68) Tseng, H.; Gage, J. A.; Shen, T.; Haisler, W. L.; Neeley, S. K.; Shiao, S.; Chen, J.; Desai, P. K.; Liao, A.; Hebel, C.; et al. A Spheroid Toxicity Assay Using Magnetic 3D Bioprinting and Real-Time Mobile Device-Based Imaging. Sci. Rep. 2015, 5 (1), 13987.

(69) Eichler, M.; Jahnke, H. G.; Krinke, D.; Müller, A.; Schmidt, S.; Azendorf, R; Robitzki, A. A. A Novel 96-Well Multielectrode Array Based Impedimetric Monitoring Platform for Comparative Drug Efficacy Analysis on 2D and 3D Brain Tumor Cultures. Biosens. Bioelectron. 2015, 67, 582-589. 